\title{
Exploring Perceptions of Role Play Activities in English as a Second Language (ESL) Classrooms
}

\author{
Nursyuhada Zakaria, Noor Hanim Rahmat, Norhartini Aripin, Nurul Hijah Jasman, \\ Nursuhaila Ibrahim
}

\begin{abstract}
Role play has long entered the ESL classroom. Many students (and teachers) enjoyed the activities that encouraged interaction in the class. Role play activities do more than just enhance social interaction (Kouvava et al. 2011)[1] among students; they can be the base for reinforcing grammar skills (Salaberry \& Scholes, 2011)[2] and presented in a context that the students are comfortable with. This study looks into the role of role-play in the ESL classroom. Students' reaction towards the use of role play is conceptualized into the classic theories of behaviourism, social constructivism and pragmatism. Quantitative data will be analysed and the results of this study will reveal interesting implications on the use of role play in the ESL classroom.
\end{abstract}

Index Terms: Constructivism, ESL classroom, Role Play, Social Interaction.

\section{INTRODUCTION}

Brown (2001)[3] reported that one of the major obstacles ESL learners face in learning to speak is the anxiety generated over the risk of "blurting things out that are wrong, stupid or incomprehensible". Role plays can be fun if learners do not have to worry over the dialogue. Role play activities can be useful to help students enjoy the lessons communicating with their peers.

According to Boudreault (2010)[4], role play activities can bring many benefits to the learners. Firstly, it allows the acquisition of meaningful and fluent interaction among learners in the target language. Next, planned role play activities can also allow learners to practice and improve on their pronunciation during communicative activities. Next, the activities also encourage the students to improve their vocabulary skills. Finally, the friendly atmosphere during role play activities helps build confidence in their ESL learners

Role play activities have also been considered to allow students to experience experiential learning. The activities are also known to improve students' self-concept and communicative competence. 59 students from two groups of second semester Diploma in Science undergone Pre-test and

Revised Manuscript Received on April 19, 2019.

Nursyuhada Zakaria, Academy of Language Studies, Universiti Teknologi MARA, Johor, Malaysia.

Dr Noor Hanim Rahmat, Academy of Language Studies, Universiti Teknologi MARA, Selangor, Malaysia.

Norhartini Aripin, Academy of Language Studies, Universiti Teknologi MARA, Johor, Malaysia.

Nurul Hijah Jasman, Academy of Language Studies, Universiti

Nursuhaila Ibrahim, Academy of Language Studies, Universiti Teknologi MARA, Johor, Malaysia. Teknologi MARA, Johor, Malaysia.

Post-test in an experimental research by Dr Mohamad Jafre Zainol Abidin et al. (2012)[5]. The control group consisted of 32 students while there were 27 students in the experimental group. The instrument used was a MultiDimensional Self-Concept test. The findings revealed that the experimental group showed significant changes in their self-concept and communicative skills compared to the control group. This is due to the situations that they faced where they should interact socially and interact with their peers and teachers.

The objective of this research is to explore the use of role play in the ESL classroom. Through Behaviourism and Social Constructivism, it is hoped that role play activities provide pragmatic competence to ESL learners.

This research is done based on the following research questions:

(a) Are there any significant differences across gender for role play and social constructivism?

(b) Are there any significant differences between Engineering and Business students for role play and social constructivism?

(c) How do Engineering and Business students perceive role play activities in ESL classrooms?

\section{LITERATURE REVIEW}

\section{A. Theoretical Framework}

Fig. 1 shows the theoretical framework of the study. Three important theories are used for the foundation of this research. They are Behaviourism, Social Constructivism and Pragmatic Competence. The authentic and real-life situations in the role-play allow learners to develop pragmatic competence. Finally, the communication among peers in the activities allows learners to learn through social constructivism.

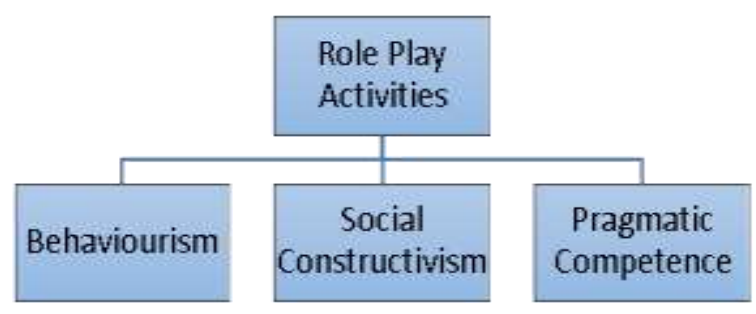

Fig. 1: Theoretical framework of the study 


\section{(i) Behaviourism By Brunner}

Behaviourist techniques are used in the classroom to promote behaviour that is desirable. According to McLeod (2008)[6], among the methods from behaviourist theory are behaviour modification and reinforcement. Role play activities that are carefully geared towards reinforcing some grammar and vocabulary skills can help in the behaviour modification of learners towards their proper usage.

(ii) social constructivism by vygotsky

According to McLeod (2007)[7], the theory of social constructivism reveals that learning takes place through the interaction activities among learners. Peer interaction does more than just allow communication to take place in a less threatening environment. It also encourages modelling of desirable behaviour among learners. Learning takes place in a non-teaching environment and learners learn through discovery.

\section{(iii) pragmatic competence}

According to Krisnawati (2011)[8], pragmatic competence is the ability of learners to use language in a contextually appropriate fashion. Pragmatic competence is considered as an important aspect of communicative competence. Role play activities allow learners to practice the use of authentic language in relevant contexts using appropriate content suitable for the desired situations in the activities.

\section{B. Past Research}

Role play activities allow learners to learn through social constructivism. The peer interaction helps learners learn social skills. The research by Chaitanya et al. (2013)[9] used role play to enhance students' participation and their ability to use English in the ESL classroom. The participants were 30 undergraduates studying Civil Engineering. The instruments used were a personal observation and informal student interviews. The students were divided into groups of five. They were given a scene from a story to act out. They were given two weeks to practice and rehearse. The findings revealed that the majority of the students reported reduced inhibitions. In addition to that, it was also discovered that the interactions of the shy students had improved their negotiating skills. Role play has also provided authentic situations for communication. Students have expressed their willingness to participate in such events to get good exposure for participating in public speaking activities. The activity has also exposed students to the necessary social skills.

Another interesting study on the advantages of role play was done by Liu and Ding (2009)[10] on 30 Chinese freshmen learning EFL. Students were assigned to be in groups of three and were given situations to act out. The findings revealed that almost $80 \%$ of the students felt comfortable to communicate freely and fluently in English during the role play. The students also reported that they learned a lot from their friends as they watched the role plays. Respondents in Magos and Politi (2008)[11] also portrayed quite similar results. They were 16 adult immigrants learning Greek as a second language. The findings showed that there was a friendly and collaborative atmosphere when the students did the role play. The respondents also stated that the role play helped their social skills acquisition as they encountered real life situations. It was also evident that the students performed the role plays more effectively when they were paired with partners of mixed abilities.

\section{METHODOLOGY}

This study adopted a quantitative approach with a descriptive research design in order to answer three research questions investigated in the study.

In total 104 repondents completed and returned the questionnaires. The respondents came from two streams of studies. The first field is Business Management which included 46 students $(44.2 \%)$, while the second field is Engineering which included 58 students $(55.8 \%)$. In terms of distribution of gender, there were 66 male students $(63.5 \%)$ and 38 female students $(36.5 \%)$ from both fields All respondents were Semester 1 students and they had undergone various role play practices and one role play assessment during their studies.

This study investigates the use of role play activities in the ESL classroom. In order to collect the data, a selfadministered survey questionnaire was employed to learn more about the respondents' perceptions regarding the use of role play activities in ESL classroom. The questionnaire was divided into five sections - (A) Demographic Profile (B) Role Play (C) Behaviourism (D) Social Constructivism and (E) Pragmatic Competence. In sections B, C, D and E, the repondents were asked to use a five-point Likert scale (Strongly Disagree, Disagree, Undecided, Agree, Strongly Agree) to respond to several statements relating to, for example, how they perceive role play activities and how role play helps them in learning.

Data from the questionnaires were tabulated and analyzed using SPSS 20.Tests were done for each section to assess the internal reliability of the items. The Cronbach'sAlpha values for each section $(\mathrm{B}, \mathrm{C}, \mathrm{D}, \mathrm{E})$ were $.925, .662, .827$, and .768 respectively. The t-test was then used to describe and compare the collected data.

\section{RESULTS \& DISCUSSION}

The findings presented here focused on investigating if the perception of role play activities differed across gender. Although much of the data here were self-reported and thus filtered through self-perception, the findings that emerged from this study are insightful. The result of the independentsamples t-test is summarized and presented below.

\section{A. The Influence of Gender on Role Play \& Social Constructivism}

The results in Table I showed the values for two sections, which were Role Play and Social Constructivism, ( $p>0.959$, $\mathrm{p}>0.096$ ) indicating that there were no significant differences between the mean responses of male and female students. This meant that the male and female students most likely had similar perceptions on the use of role play activities in ESL classroom. 
Table I: Significant values for gender versus role play and social constructivism

\begin{tabular}{cccccc}
\hline Sections & F & Sig & t & df & $\begin{array}{c}\text { Sig (2- } \\
\text { tailed) }\end{array}$ \\
\hline Role Play & 3.09 & .08 & -.05 & 100 & 0.959 \\
$\begin{array}{c}\text { Social } \\
\text { Constructivism }\end{array}$ & 1.17 & .28 & 1.68 & 99 & 0.096 \\
\hline
\end{tabular}

\section{B. The Influence of Programmes on Role Play \& Social Constructivism}

The results in Table II showed the values for two sections, which were Role Play and Social Constructivism, ( $p>0.597, p>0.991)$ indicating that there were no significant differences between the mean responses of Business Management and Engineering students. This meant the students from both programmes most likely had similar perceptions on the use of role play activities in ESL classroom.

Table II: Significant values for programmes versus role play and social constructivism

\begin{tabular}{cccccc}
\hline Sections & F & Sig & t & df & $\begin{array}{c}\text { Sig } \\
(2- \\
\text { tailed })\end{array}$ \\
\hline Role Play & 2.031 & .157 & .530 & 100 & 0.597 \\
$\begin{array}{c}\text { Social } \\
\text { Constructivism }\end{array}$ & 2.122 & .148 & -.012 & 99 & 0.991 \\
\hline
\end{tabular}

In Section B of the questionnaire (Role Play), there were six items tested to investigate how the students perceived the use of role play activities (Refer Appendix). There were no significant differences observed between Business and Engineering students as their mean scores for most of the items in this section were similar. However, two items that showed some differences were Item B2 and B3. As reflected in Fig. 2, the Business students achieved a higher mean score compared to the Engineering students for these two items. This means that the Business students responded to their partner in English more often than the Engineering students did during the role plays activities. The Business students also believed that by doing role play activities, they could practice their conversational skills. This finding is in accordance with the studies by Chaitanya et al. (2013)[9], Dr Mohamad Jafre Zainol Abidin et al. (2012)[5] and Magos and Politi (2008)[11] who also reported improved social skills among learners who participated in role play activities.

\section{Role Play Participation Among Business and Engineering Students}

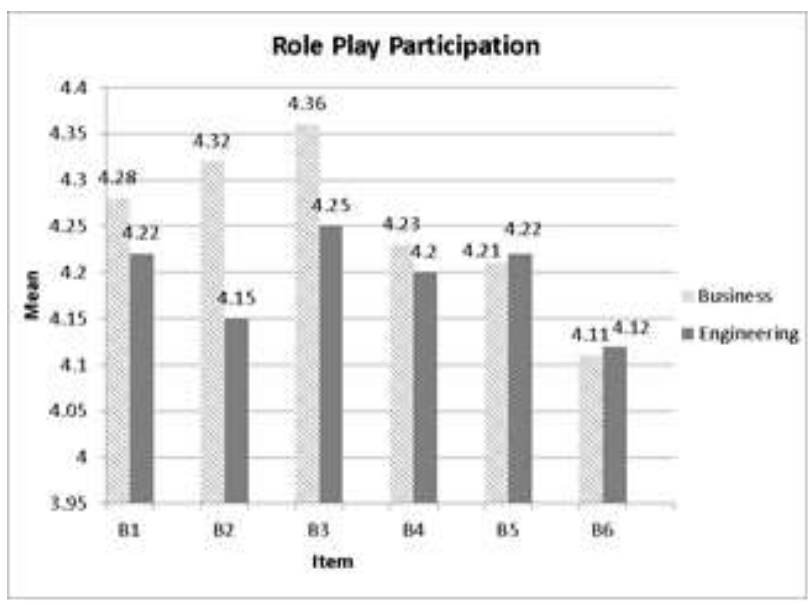

Fig. 2: Role play participation

D. Social Constructivism Among Business and Engineering Students

In section D of the questionnaire (Social Constructivism), there were eight items tested to investigate how the students interacted with their peers during the role plays (Refer Appendix). There were three items that showed some differences between Business and Engineering students, which were Item D19, D23, and D24. For Item D19, the Engineering students scored a higher mean score compared to the Business students. This showed that the Engineering students agreed that their partner guided them during the role play sessions. As for Item D23, it was shown in Fig. 3 that Engineering students obtained a slightly higher mean score compared to the Business students. This was evident that the Engineering students learnt from their friends more than the Business students did when they watched role plays. This finding is in accordance with Liu and Ding (2009)[10] where the students in their study also revealed that they learned a lot while watching their friends doing the role play. Another item that portrayed a difference was item D24, where the Business students scored a higher mean score than the Engineering students. The Business students preferred to have a partner that was better than them. This could mean that they depended on their partner to do role plays and they learned better that way. The finding is supported by Magos and Politi (2008)[11] where they found that role play could be more effective when the roles were given to partners who have different abilities.

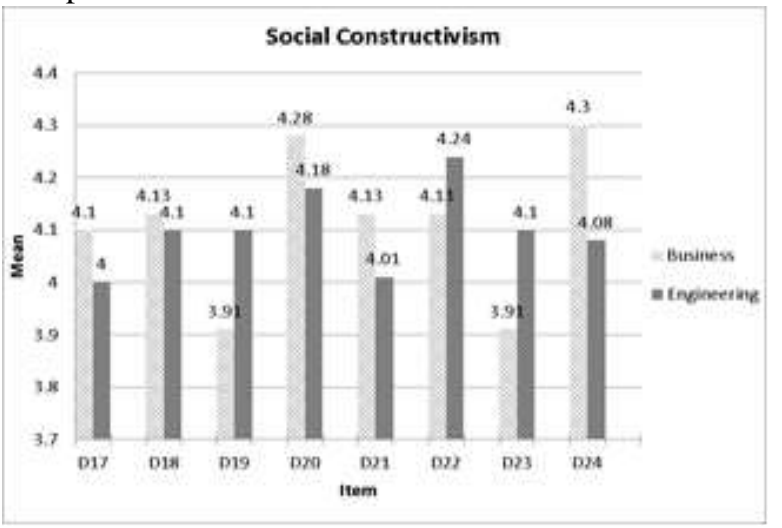

Fig. 3: Social constructivism 
International Conference on Recents Advancements in Engineering and Technology (ICRAET-18) |15th and 16th March 2019|Siddhartha Institute of Technology \& Sciences, Telangana, India.

\section{CONCLUSION}

Role play activities can be beneficial to both male and female learners. Based from the findings of the study, both male and female respondents had similar perceptions towards the use of role play in the ESL classroom. In terms of the programmes they were in, the results showed that the programmes did not influence the respondents' perceptions towards the use of role play.

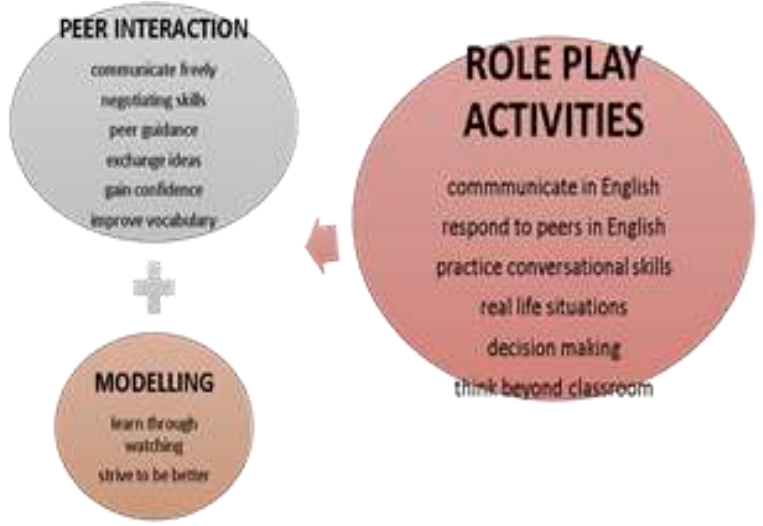

Fig. 4: Summary of the findings

Fig. 4 reveals the detailed summary of the findings in the research. Based on the respondents' responses, it can be seen that role play activities help learners communicate in English, practice conversational skills in real life situations, make decisions as well as think beyond the classroom setting. The social setting further enhances learners' peer interaction, allowing them to practice negotiating skills, exchange ideas and also gain confidence to communicate through modelling of behavior in the group dynamics.

Role plays can be used to teach more than just language and communication skills. The activities performed help scaffold learners towards social constructivism when they are given the opportunity to construct new knowledge through interactions.

Future research could attempt to analyse the conversations qualitatively and explore problem solving and thinking skills of the learners in social interactions.

\begin{tabular}{|c|c|c|c|c|c|c|c|}
\hline B & & Statements & 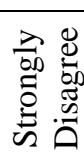 & 递 & 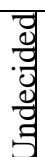 & 包 & 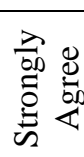 \\
\hline \multirow{6}{*}{ 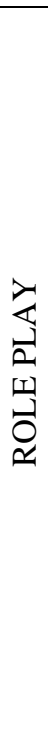 } & 1 & $\begin{array}{l}\text { During role plays, I } \\
\text { use English for } \\
\text { communication. }\end{array}$ & & & & & \\
\hline & 2 & $\begin{array}{l}\text { During role plays, I } \\
\text { respond to my } \\
\text { partner in English. }\end{array}$ & & & & & \\
\hline & 3 & $\begin{array}{l}\text { Role plays allow me } \\
\text { to practice my } \\
\text { conversational skills. }\end{array}$ & & & & & \\
\hline & 4 & $\begin{array}{c}\text { Role plays allow me } \\
\text { to practice real life } \\
\text { situations. }\end{array}$ & & & & & \\
\hline & 5 & $\begin{array}{c}\text { Role plays help me } \\
\text { to learn decision } \\
\text { making. }\end{array}$ & & & & & \\
\hline & 6 & $\begin{array}{l}\text { Role plays help me } \\
\text { think beyond my } \\
\text { classroom. }\end{array}$ & & & & & \\
\hline
\end{tabular}

\section{APPENDIX}

Items in Section B of the questionnaire Items in Section $\mathrm{D}$ of the questionnaire

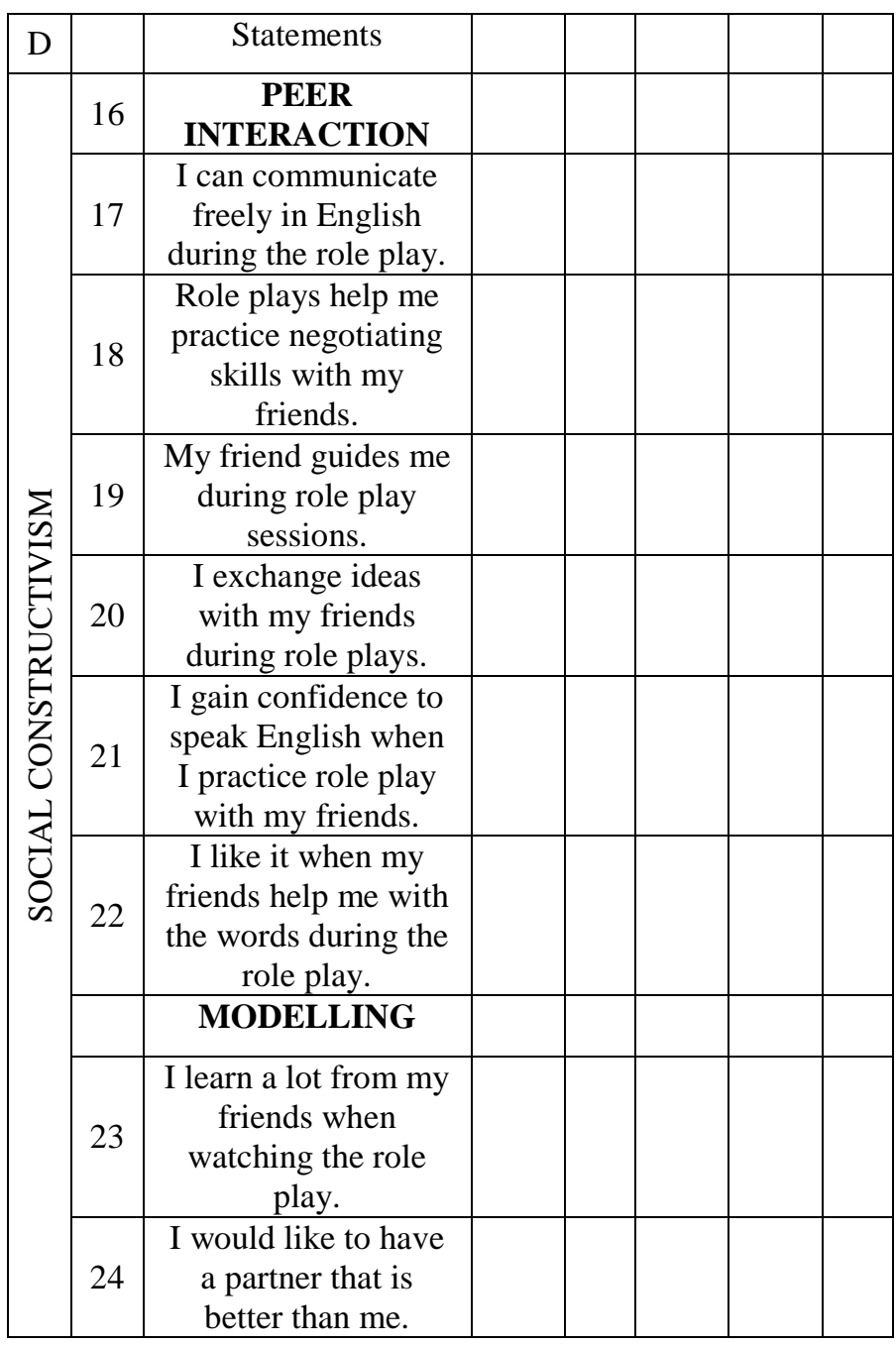

\section{REFERENCES}

1. S. Kouvava, K. Antonopoulou, S. Zioga, C. Karali. (2011). The influence of musical games and role play activities upon primary school children's self-concept and peer relationships. Procedia-Social and Behavioral Science, 29, 1160-1167.

2. M.R. Salaberry and J. Scholes. (2011). Strategic roleplays in a paired-testing format: putting a language lab into a rational pedagogical use. Texas Papers in Foreign Language Education, 15 (1).[Online]. Available:https://studentorgs.utexas.edu/flesa/TPFLE_Ne w/Issues/Summer\%202011/5.\%20Salaberry\%20and\%20 Scholes.pdf

3. H.D. Brown. (2011). Teaching by Principles-An Interactive Approach to Language Pedagogy. NY: Addison Wesley Longman.

4. C. Boudreault. (2010). The benefits of using drama in the ESL/EFL classroom. The Internet TESL Journal. [Online]. Available: http://iteslj.org/Articles/BoudreaultDrama.html

5. Dr Mohamad Jafre Zainol Abidin, Siti Rafizah Fatimah Osman and MoniroSadat Hosseini. (2012). Taking the line of least resistance. International Journal of Learning 
\& Development, 2 (2), 258-270.

6. S. McLeod. (2008). Brunner. Simply Psychology. [Online]. Available: http://www.simplypsychology.org/bruner.html

7. S. McLeod. (2007). Lev Vygotsky. Simply Psychology. [Online]. Available: http://www.simplypsychology.org/vygotsky.html

8. E. Krisnawati. (2011). Pragmatic competence in the spoken english classroom. Indonesian Journal of Applied Linguistics, 1 (1), 100-110.

9. E.K. Chaitanya and K.V. Ramana. (2013). Role play - an integrated approach to enhance language skills (LSRW) of the ESL learners - A Collaborative Action Research Report. Language in India, 13 (1), 469-482.

10. F. Liu and Y. Ding. (2009). Role-play in English Language Teaching. Asian Social Science, 5 (10), 140143.

11. K. Magos and F. Politi. (2008). The creative second language lesson: the contribution of the role-play technique to the teaching of a second language in immigrant classes. RELC Journal, 39(1), 96-112.

\section{AUTHORS PROFILE}

Nursyuhada Zakaria is currently teaching at Universiti Teknologi MARA (UiTM) Pasir Gudang, Malaysia. Her research interests include teacher education and curriculum and assessment.

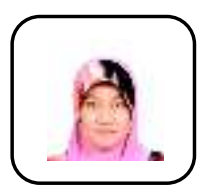

Dr Noor Hanim Rahmat is currently teaching at Universiti Teknologi MARA (UiTM) Shah Alam, Malaysia. Her research interests include writing methodology and sociolinguistics.

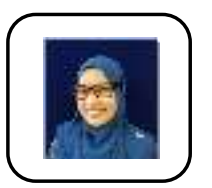

Norhartini Aripin is currently teaching at Universiti Teknologi MARA (UiTM) Pasir Gudang, Malaysia. Her research interests include psychology of education and writing.

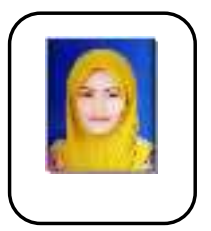

Nurul Hijah Jasman is currently teaching at Universiti Teknologi MARA (UiTM) Pasir Gudang, Malaysia. Her research interest is in linguistics.

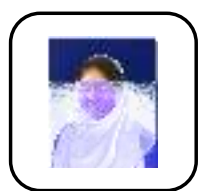

Nursuhaila Ibrahim is currently teaching at Universiti Teknologi MARA (UiTM) Pasir Gudang, Malaysia. Her research interests include linguistics and learning strategies. 